\title{
Economic Transformation Impact on the Modernization of a Mineral Resource Industry Cluster
}

\author{
Evgeny Zhernov ${ }^{1, *}$, Evgenia Nekhoda $^{2}$, and Mariana Petrova ${ }^{3}$ \\ ${ }^{1}$ T.F. Gorbachev Kuzbass State Technical University, Department of Economics, 650000 Kemerovo, \\ 28 Vesennyaya St., Russian Federation \\ ${ }^{2}$ National Research Tomsk State University, Department of Strategic Management and Marketing, \\ 634050 Tomsk, 36 Lenin Ave., Russian Federation \\ ${ }^{3}$ St. Cyril and St. Methodius University of Veliko Tarnovo, Veliko Tarnovo, Bulgaria
}

\begin{abstract}
The purpose of the study is to show the economic transformation impact on solving the problems of modernization of the socio-economic sphere of the mineral resource industry cluster operating in the mining region. The object of the research is the mineral resource industry cluster as a center of interaction between state, science, education and business for the implementation of innovative scientific, technical and socio-economic projects. The subject of the article is socio-economic relations concerning nature, focused in the mineral resource industry cluster of the mining region. The problems of sustainable development and modernization of the mineral resource industry cluster of the mining region are considered in terms of the socio-ecological-economic approach methodology, taking into account the economic transformation in the cluster, which ensures the scientific novelty of the study. The scientific merit of the study is the determination of the impact of the change in the types of economy on solving the problems of modernization of the socioeconomic sphere of the cluster, based on the parity of nature and the economy in the mining region. It has been shown that clustering involving the potential of a world-class regional scientific and educational center is an effective mechanism for such modernization. The practical relevance of the study lies in the fact that its results can be used to clarify, taking into account the proposed approach, the state strategy of support and development of clusters, as well as regional cluster policy.
\end{abstract}

\section{Introduction}

The new economic reality of the coming era of resource depletion is characterized by a transition from resource-extracting economy to resource-saving economy, from linear economy to circular one, from private property economy to sharing economy. Most clearly and contradictory, these changes are manifested, in our opinion, in the mineral resource industry clusters created in resource-extracting regions. Therefore, the study of the impact

\footnotetext{
*Corresponding author: zhee.eti@kuzstu.ru
} 
of this economic transformation on the modernization of such a cluster in the mining region of Kuzbass is an urgent task.

The objectives of the study are: 1) to formulate the prerequisites for the formation of the mineral resource industry cluster in the mining region; 2) to consider universal problems caused by contradictions between the structure of nature as a mineral resource in the mining region and the functioning of the economy as a part of society in new organizational and managerial cluster forms. The scientific novelty of the study lies in the application of the socio-ecological-economic approach methods, which take into account the objective process of changes in the types of economy in the mineral resource industry cluster of the mining region. The scientific merit lies in determining the impact of economic transformation on solving the problems of modernizing the socio-economic sphere of the cluster, based on the parity ratio of nature and economy in the mining region. The practical relevance of the study is related to solving the priority task of raising the rate of socioeconomic development of the region to improve the quality and standard of living of its population through the formation and development in the Kemerovo region - the significant mining region of Western Siberia - a competitive innovative mineral resource industry cluster. The practical relevance of the study lies in the fact that its results can be used to clarify the state strategy for the support and development of the mineral resource industry cluster, as well as to develop a regional cluster policy for the mining region.

This purpose is achieved by scientific substantiation of the cluster approach to the combination of nature and economy of the mining region, taking into account foreign experience in the formation of resource-saving economy as opposed to resource-extracting economy, circular economy instead of linear one, sharing economy instead of private property economy.

\section{Materials and Methods}

The socio-economic topics of innovative cluster development are relatively new for resource-extracting regions of the Russian Federation. Therefore, the experience of states, where innovative mineral resource industry clusters are efficient for the country in terms of both environmental conservation and creation of high-tech jobs and contribution to the gross regional product, is in demand in this case. The scientific foundation of this experience is the theory of the development of industrial agglomerations of the 2008 Nobel laureate P. Krugman [1] and the concept of industry clusters by M. Porter [2].

Regional differences in domestic competitiveness and the geographical extent of competitive advantage were investigated by $M$. Enright. According to his theory, competitive advantages are not created at the national, but at the regional level. The author gave the following definition: "A regional cluster is a geographic agglomeration of firms operating in one or more related economy sectors" [3]. We will take it as a basis in our study.

In world practice, there are two main approaches to cluster formation. The classical liberal (Anglo-Saxon) approach, proposed in the 1980s and 90s by M. Porter, is based on the self-organization of economic agents within the framework of "free market" without direct government intervention and/or support. The modern European approach, called the "poles of competitiveness", has been developing since 2006 in France. It is based on a partnership of business, central and local authorities. The state is interested in the global competitiveness of its economy and the achievement of the world-class "pole of competitiveness"; therefore, it provides support in various forms in the framework of the implementation of development strategies for territories. The second approach, in our opinion, is more consistent with the present Russian economy and therefore seems more 
preferable. It can be considered as a socio-ecological-economic approach by virtue of taking into account the interests of the territory, which allows it to be used in this study.

The participation of state structures and educational institutions in the innovation sphere of developed countries has revealed general recommendations regarding state support for the modernization of resource-extracting regions industry based on innovation [4-6]. An effective means of solving problems is such an organizational and managerial innovation as a cluster, the strong point of which is cooperation, due to the modern transformation of the economy in the direction of resource-saving based on science and education. N. Radjou and J. Prabhu [7] write about the current upsurge of resource-saving economy in the developed countries. Foreign experience and recommendations can be successfully used to justify the modernization of the mineral resource industry clusters of resource-extracting regions in order to solve their main problems.

We consider the cluster approach as the basis of innovative and socially oriented development of mineral resource industry of the resource-extracting regions. Studies of the role of the cluster in this process are aimed at the interconnected acquisition and practical use of new scientific and humanitarian knowledge. In this case, we are talking about both the basic laws of the structure of mineral resources (natural, design and engineering aspects), and the laws of functioning and development of society and an individual (social and humanitarian aspects). The purpose of such studies is to reveal the contradictions between the structure of nature as a mineral resource of the mining region, and the functioning of the economy as a part of social system [8].

The study of new organizational and managerial cluster forms that clearly reflect the change in economic models in the transition to sustainable development is of particular importance for the mining region. The important tasks of this stage are not only the creation of nature-like technologies for mining and processing of minerals, but also the development of new concepts within the framework of a socio-economic approach to the development of mineral resource for the sustainability of the mining industry. These are, first of all, the concepts reflecting the objective transformation of the economy in the cluster: from ownership economy to sharing economy, from resource-extracting economy to resourcesaving economy, from traditional linear economy to circular economy; extension of the horizontal network model of the economy. The latter optimizes consumption through tools such as shared ownership, short-term lease of idle production capacities, the exchange of surplus resources and information/knowledge. All of these new models of economy are ultimately based on human knowledge.

\section{Results and Discussion}

The scientific substantiation of sustainable development and modernization of the socioeconomic sphere of the mineral resource industry clusters of the mining regions, in our opinion, includes: 1) identification of the real prerequisites for the formation of the mineral resource industry clusters; 2) determination of universal problems of sustainable development and modernization of the object of study; 3) determination of the impact of economic transformation on the solution of these problems.

The identification of the objective prerequisites for the formation of mineral resource industry clusters is based on the comprehensive analysis of the industry structure of the economy that has been developed in the region, the rate of development of the mineral resource industry clusters' production facilities, and the extent of scientific support for innovation. The analysis showed that there are real prerequisites for sustainable development and modernization of the socio-economic sphere of the mineral resource industry cluster of Kuzbass as a mining region: on the one hand, there are comprehensive 
scientific, technical and educational capacities, and on the other hand, there are distinctive features of the territory provided with various natural resources for many years to come.

In the process of further development, new prerequisites for the modern structural adjustment of the economy are created. Structuring is considered a sign of life and development [9]. For the economic creation in the mining region, it is necessary, first of all, to scientifically structure enterprises into large complexes, such as mineral resource industry clusters. Currently, innovative and technological changes in the industry of the Kuzbass mineral resource industry clusters are taking place within the framework of III and IV technological waves. Therefore, bringing the structure of the regional economy in line with the achievements of developed countries in the transition to a knowledge-based economy cannot be ensured. Therefore, it is necessary to focus efforts on the development of key areas of V and VI technological waves. This requires a focused state scientific, technical and innovation policy. Its main task should be the creation of an innovative potential that will ensure the above transformation of the economy of the mineral resource industry clusters of the mining regions, primarily due to the rational integrated development of natural mineral resources.

The main universal problems of sustainable development and modernization of the socio-economic sphere of the mineral resource industry cluster are, in our opinion: the consistent implementation of targeted state-owned scientific, technical and innovative strategies and policies; selection of mineral resource industry cluster management tools for a specific region; organization of the work of the updated infrastructure elements of the mineral resource industry cluster, including interaction with the world-class scientific and educational center (hereinafter - WCSEC).

Sustainable development and modernization of the industry and the socio-economic sphere of the mineral resource industry cluster of the resource-extracting regions are determined by the efficiency of the state industrial, innovative, and environmental policies. Government requirements for business are being tightened in terms of the rational use of natural resources throughout the world. Russia tries to follow them. However, the strategic guidelines developed by the government often differ from the actions implemented at the local level. This situation largely causes the contradictions in the innovation process of clustering, especially in resource-extracting regions.

In order to resolve these contradictions, the mineral resource industry cluster should be created on the basis of the harmonious development of production and the sphere of life support, and, if necessary, to increase the level and quality of life of the population of the territory, based on the rapid development of this sphere. To this end, the tasks of creating the general conditions for the development of industry along the path of neoindustrialization [10], creating a favorable environment for innovative search and use of nature-friendly technologies for mining and processing of raw materials are highlighted. The solution of these problems stimulates various forms of cooperation and partnership between state, scientific, educational and entrepreneurial sectors, which reduces the known risks of innovation. So, for example, in 2019, an Agreement on cooperation between the Government of Kuzbass and the Association for the Development of Clusters and Technology Parks of Russia was signed. The parties will jointly work on the creation and development of industrial clusters in Kuzbass, which will become a platform for the introduction of modern innovative technologies. State financial support may amount to 1 billion rubles from the federal budget for each member of the industrial cluster.

The diversities of the natural potential and the specificity of the development of the industrial sector of the regions lead to the difference in the management tools of the mineral resource industry cluster for each region. The mining regions, including Kuzbass, require special tools. The use of program-targeted and administrative mechanisms seems advisable for them, as regions with less innovative development. Among these mechanisms - state 
support, both organizational in nature, and in the form of direct financing of innovation. The development program of the Kuzbass innovation cluster "Integrated processing of coal and anthropogenic waste" is aimed at implementing pilot innovative projects in the field of clean coal energy, coal chemistry and processing of anthropogenic waste. This makes it possible to consider this cluster as an example of the current innovative energy cluster and environmental management in a single system "nature - economy".

Solving the problems of sustainable development and modernization of the socioeconomic sphere of the mineral resource industry clusters of the resource-extracting regions is possible by developing innovative technologies, primarily in the mineral resource industry itself. It should be emphasized here that today it is as knowledge-intensive and high-tech as the advanced branches of the processing industry. In this regard, the development of the mineral resource industry cluster requires a significant increase in the cost of research and development work with their high efficiency. For this, it is necessary to involve institutes of the Russian Academy of Sciences and state centers such as WCSEC on the basis of business contracts.

The regional policy in the field of development of the mineral resource industry clusters is implemented by creating a favorable economic and legal environment for innovation and formation of non-productive or social infrastructure. The latter includes institutions of education and science, health and culture, consumer services. This infrastructure is designed to meet the needs of people, guarantee them the necessary life standard and quality, as well as provide training for highly qualified personnel, which is especially important for the innovation cluster.

The considered elements of social infrastructure operate either at the expense of the state and local authorities or through private initiative, and therefore interact little with each other. As a result, one of the main problems in the development of the mineral resource industry clusters of the mining regions is the autonomous operation of infrastructure elements, which does not have a constant close relationship with industry. The regional pilot WCSEC "Kuzbass" is called to unite them into a single whole. The innovative mineral resource industry cluster, closely interacting with the WCSEC, is both an organizational and economic mechanism and a social institution of a knowledge-based economy. In this form, it is aimed both at increasing the competitiveness of the economy, and at developing the social sphere and observing the principle of nature conformity. The management of the mineral resource industry cluster will achieve great success in collaborating with universities and research organizations. Only in this interaction will it be possible to create an effective mineral resource industry cluster that has a huge impact on the socio-economic and environmental status of the Kemerovo region. The impact of economic transformation on the prerequisites for the formation and unresolved problems of sustainable development and modernization of the mineral resource industry cluster are presented in the table 1.

Table 1. Transformation of the economy as a way of creating the prerequisites and solving problems of the mineral resource industry clusters.

\begin{tabular}{|l|l|l|l|l|}
\hline \multirow{2}{*}{$\begin{array}{l}\text { Transformation } \\
\text { of the economy }\end{array}$} & $\begin{array}{l}\text { Creating the } \\
\text { prerequisites }\end{array}$ & \multicolumn{3}{|c|}{ Problems } \\
\cline { 3 - 5 } & $\begin{array}{l}\text { Implementa- } \\
\text { tion of state } \\
\text { strategy and } \\
\text { policy }\end{array}$ & $\begin{array}{c}\text { Selection of } \\
\text { management } \\
\text { tools }\end{array}$ & $\begin{array}{c}\text { Infrastructure } \\
\text { update }\end{array}$ \\
\hline $\begin{array}{l}\text { 1. From resource- } \\
\text { extracting to } \\
\text { resource-saving }\end{array}$ & $\begin{array}{l}\text { Territorial } \\
\text { natural capital }\end{array}$ & $\begin{array}{l}\text { Industrial and } \\
\text { territorial } \\
\text { sharing of } \\
\text { natural } \\
\text { resources }\end{array}$ & $\begin{array}{l}\text { Territorial } \\
\text { analysis for the } \\
\text { implementation of } \\
\text { an integrated } \\
\text { management } \\
\text { system }\end{array}$ & $\begin{array}{l}\text { Development of } \\
\text { nature-like } \\
\text { technologies at the } \\
\text { WCSEC }\end{array}$ \\
\hline
\end{tabular}




\begin{tabular}{|l|l|l|l|l|}
\hline $\begin{array}{l}\text { 2. From linear to } \\
\text { circular }\end{array}$ & $\begin{array}{l}\text { Territorial } \\
\text { social capital of } \\
\text { linking industry } \\
\text { with science }\end{array}$ & $\begin{array}{l}\text { Compliance } \\
\text { with the } \\
\text { principle of } \\
\text { conformity to } \\
\text { nature }\end{array}$ & $\begin{array}{l}\text { Territorial } \\
\text { rationalization, the } \\
\text { use of efficient } \\
\text { production and } \\
\text { engineering ties } \\
\text { through } \\
\text { cooperation }\end{array}$ & $\begin{array}{l}\text { Improvement of } \\
\text { technological } \\
\text { processes of mining } \\
\text { and processing of } \\
\text { minerals at the } \\
\text { WCSEC }\end{array}$ \\
\hline $\begin{array}{l}\text { 3. From } \\
\text { ownership to } \\
\text { sharing }\end{array}$ & $\begin{array}{l}\text { Territorial } \\
\text { cooperation. } \\
\text { Human capital } \\
\text { development }\end{array}$ & $\begin{array}{l}\text { The use of } \\
\text { administrative } \\
\text { and program- } \\
\text { targeted } \\
\text { mechanisms }\end{array}$ & $\begin{array}{l}\text { Horizontal } \\
\text { integration, } \\
\text { cluster-based } \\
\text { organizational } \\
\text { technology }\end{array}$ & $\begin{array}{l}\text { Sharing of research, } \\
\text { development and } \\
\text { production complex. } \\
\text { Collaboration with } \\
\text { universities }\end{array}$ \\
\hline
\end{tabular}

During the period of economic transformation and under its influence, the interconnection of enterprises and organizations of the cluster on the basis of sharing natural and anthroposocial capital increases. Industrial companies and the mineral resource industry cluster organizations should jointly develop and implement various schemes for sharing and circular economies. For this purpose, two directions must be followed: 1) integration of their own procurement, production and marketing chains with the chains of those producers whose waste or by-products can be used as valuable raw materials; 2 ) income from the rental of idle production facilities to companies experiencing a shortage of them. Such a dual strategy within the cluster allows developing innovative small and medium-sized enterprises, to achieve the greatest cost-efficiency and to find sources of additional income. The synergy model of by-products also has a beneficial effect on the environment, reducing the total emissions of both industries into the atmosphere.

The solution of the problems considered by forming new mineral resource industry clusters and improving the existing ones, taking into account the experience of developed countries in transforming the economy, will allow for the efficient modernization of both the industry and the social sphere of the mineral resource industry in the mining region. The population of the region is concerned, first of all, with such important aspects of its life as environment and social harmony. The business model of the mineral resource industry cluster of the resource-extracting region should include mandatory elements of regular assistance to the region in solving social problems, combined with its commercial interests. To increase the confidence of residents, large cluster companies should create, along with added value, social capital, have less harmful effects on the environment, thereby preserving natural resources of the territory they operate it.

\section{Conclusion}

The application of the socio-ecological-economic cluster approach methodology has made it possible to determine the impact of objective economic transformation on the prerequisites and unresolved problems of the formation of the mineral resource industry clusters of the mining regions. Taking this impact into account in state policy will make it possible to create in Kuzbass a more advanced economic mechanism for sustainable development and modernization of mineral resource industry clusters, based on the unity of the forces of nature with the creative potential of man and society, concentrated in the economy. The main advantage of applying the cluster approach in regional development is that it ensures the high importance of the territorial and social aspects of economic development. The socio-economic effect of the innovative mineral resource industry cluster is manifested in the following areas: increasing the productivity and competitiveness of companies of leading sectors of the regional economy; enhancing the innovative potential of mineral industry by actively including science and education institutions in the 
implementation of the cluster policy; stimulating the establishment and development of new innovative small and medium-sized companies adapted to local conditions; increasing competitiveness and innovative socio-economic development of the mining region. These activities give a synergistic effect: achievements in one of them increase the region's position in the other one.

\section{References}

1. M. Fujita, P. Krugman, A. J. Venables, The spatial economy: cities, regions, and international trade (The MIT Press, Cambridge, Massachusetts; London, 1999)

2. M. E. Porter, The competitive advantage of nations (Macmillan, London; Free Press, New York, 1990)

3. M. J. Enright, The geographic scope of competitive advantage. In: E. Dirven, J. Groenewegen, S. van Hoof (eds.), Stuck in the Region? Changing scales for regional identity (Koninklijk Nederlands Aardrijkskundig Genootschap, Utrecht, 1993)

4. Directive 2012/19/EU of the European Parliament and of the Council on waste electrical and electronic equipment (WEEE) (The European Parliament and the Council of the European Union, Strasbourg, 2012)

5. The Natural Capital Impact Group of the University of Cambridge Institute for Sustainability Leadership. URL: www.cisl.cam.ac.uk

6. The Natural Capital Project of Stanford University. URL: www.naturalcapitalproject.stanford.edu (2020)

7. N. Radjou, J. Prabhu, Frugal innovation: how to do more with less (Economist, London, 2015)

8. E. Zhernov, E. Nekhoda, D. Peters, E3S Web of Conferences, 105, 04012 (2019)

9. S. Zhironkin, S. Demchenko, G. Kayachev, M. Ryzhkova, O. Zhironkina, E3S Web of Conferences, 41, 04011 (2018)

10. L. Kusurgasheva, O. Nedospasova, E. Zhernov, E3S Web of Conferences, 15, 04007 (2017) 